$\begin{array}{r}\text { Volume and Issues Obtainable at Center for Sustainability Research and Consultancy } \\ \text { Journal of Business and Social Review in Emerging Economies } \\ \text { ISSN: 2519-089X (E): 2519-0326 } \\ \text { Volume 6: No. 4, December } 2020 \\ \text { JSRᄃ } \\ \text { Journal homepage: www.publishing.globalcsrc.org/jbsee } \\ \hline\end{array}$

\title{
Corporal Punishment Act in Public Schools: A Phenomenological Analysis of Perceptions of Practitioners
}

\author{
${ }^{1}$ Nargis Abbas, ${ }^{2}$ Beenish Ijaz Butt, ${ }^{3}$ Uzma Ashiq \\ ${ }^{1}$ Assistant Professor, Department of Education, University of Sargodha, Pakistan, \\ nargis.abbas@uos.edu.pk \\ ${ }^{2}$ Assistant Professor, Department of Social Work, University of Sargodha, Pakistan, \\ beenish.ijaz@uos.edu.pk
}

${ }^{3}$ Lecturer, Department of Social Work, University of Sargodha, Pakistan, uzma.ashiq@uos.edu.pk

\begin{tabular}{l}
\hline ARTICLE DETAILS \\
\hline History \\
Revised format: November \\
2020 \\
Available Online: December \\
2020
\end{tabular}

Keywords

Corporal punishment, teachers, students, discipline, state

JEL Classification M10, M12

\section{ABSTRACT}

Corporal punishment (CP) is a conspicuous and serious matter of Pakistani schools. In response to this prevalent social problem the government of Pakistan like other countries has legislated against corporal punishments through Corporal Punishment Act, 2010 which restricts $\mathrm{CP}$ of every type in all educational institutes of the country. The said policy was promulgated to secure the child rights in the country but the flip side of the policy presents a different picture. This paper aims at investigating challenges faced by of the elementary public-school teachers as policy practitioners about the ban on corporal punishment by the government. This paper is based on qualitative social research methodology and used phenomenological research approach. Phenomenological interviews were used to collect the data until data reached at saturation. The data was analyzed by following the overall process guided by Creswell. Major derived themes from data were Perceptions of teachers regarding ban on Corporal Punishment, Post Corporal Punishment Legislation Challenges and Opinion of teachers regarding Government policy on CP followed by several sub-themes. It was concluded that the state vision to promote child welfare is hardly seen through its policies as at the end the welfare of the target group must be assured not doubted.

(C) 2020 Center for Sustainability Research and Consultancy Pakistan under a Creative Commons Attribution-NonCommercial-ShareAlike 4.0

Corresponding author's email address: nargis.abbas@uos.edu.pk

Recommended citation: Abbas, N., Butt, B. I. \& Ashiq, U. (2020). Corporal Punishment Act in Public Schools: A Phenomenological Analysis of Perceptions of Practitioners. Journal of Business and Social Review in Emerging Economies, 6(4), 1415-1425

\section{Introduction}

Corporal punishment is a documented problem of several societies around the globe. In schools, corporal punishment (CP) considers to be an effective solution for children for the sake of guidance. The cane is most common gadget in this regard of child betterment. In Asia, Europe and the European 
colonies this cane was also known as junior or light cane that used to be compulsory in the classroom in the 19th to 20th centuries, to oversee young school children. Another term "spanking" is also found in literature which means "hitting a child on their buttocks or extremities using an open hand" (Gershoff \& Grogan-Kaylor, 2016, pg. 453) However, in Human Rights Activists' vision, corporal punishment is a torture. In their observation physical punishment is a form of domestic violence as well as child abuse to defend human rights. While, for South Asian children, the corporal punishment is a usual concept in their routine life of at domestic level, in institutes, at work and in neighborhoods. Although, the Convention on the Rights of the Child (CRC) states that young ones are respectable having equal right to honor and respect. Whereas, in South Asian countries CP is thought to be mandatory for child's development, to aid in cognition and to maintain order (UNICEF, 2012). Such is the commonly observed belief in public sector schools of this region like India, Pakistan, Bangladesh, Nepal and Afghanistan. In contrast to the above said situation, defenders of physical punishment assert that utilization of sticks is responsible for extraordinary outcomes in children. Absence of corporal punishment, when students will reach till high school, they will be more rebellious and the school would slide into chaos (Mararike, 2005). Fournier (2004), a French educational expert, supported physical punishment by saying that spanking should alone not be used in education. The USA Criminal Code explains power to be used by a parent, a guardian or any other responsible person consider in their honest opinion when it is gravely needed for looking after or advantage of that young one in order to rectify his/her misconduct. Moreover, defenders of corporal punishment claim that those students give best who receive corporal punishment and they believed without corporal punishment pupils become more disrespectful by the time that come to high school level (Marairke, 2005). It is believed that teacher's corporal punishment is a source of maintaining discipline and shaping the behavior of children. Customary ways of life provide conformity to the effectiveness of corporal punishment (Raj, 2011). Traditional believe about the concept of corporal punishment confirmed that it is the best way to shape the behavior of children (Shmueli, 2010).

On contrary, an extensive body of research also revealed corporal punishment as an ineffective way of handling the matter rather it is detrimental, destructive and injurious to the personality of the child. Corporal punishment or canning in earlier years of school causes high level of aggression, anxiety, depression, anger and sometime serious psychological issues with the students in later years of school and even in their practical life (Gershoff et al., 2018, Gershoff et al., 2019). Corporal punishment makes the children aggressive, anti-social and lemmatizes their internal skills. Further, these effects persist across the cultural, familial and geographical boundaries. As Gershoff (2002) concluded about the longterm effects of corporal punishment. Corporal punishment increased child delinquency, moral internalization, as well as antisocial and aggressive behavior among children.

Pakistan has signed the UN pact on the entitlement of children, mentioning all judicial and management steps should be taken to assure law making for providing defense of children (UNCRC, 1990). However, in case of Pakistan, corporal punishments have occupied schools for nearly more about one and half century. In this case, multiple incidents had been reported from government/non-government schools, maracas) wherever punishments are institutionally deep-seated. Moreover, it is estimated that due to $\mathrm{CP}$ nearly 35,000 Pakistani students are unable to continue their education and out of every five students, four are susceptible to fathers/mothers, instructors and elders (Hadi, 2014).

Corporal punishment is a conspicuous and serious matter of Pakistani secondary institutes. It is obvious from documented report as, "Corporal punishment remained dominant in enormous number of secondary institutes with sticks, shoes, scales, iron bars and poles. For most of times this beating resulted in complicated injuries and the reason behind this punishment was unavailability of required textbook, mistaken answer to a question and incomplete assigned work (Human Rights Commission of Pakistan, 2003, p. 308).

In response to this prevalent social problem the government of Pakistan like other countries has legislated against corporal punishments through Corporal Punishment Act, 2010 which defines corporal punishment under section 3.2 as 
Corporal punishment of every type is outlawed in all educational institutes either formal or informal, government or non-government institutes, and in government based or nongovernment children supervision centers such as foster homes or any of such sorts.

But in the next section 3.3 it is stated that

Disciplinary steps and reforms that concerning the children must be carried out without influencing that child's self-esteem and never should any action of corporal punishment be taken that demolishes a child's physical or psychological well-being or sentiments of a child.

The private sector schools, prior to this act, have already taken actions and prohibited the physical punishment to the students in order to maintain their standards with American and European system of education. While, there are mixed views of teachers on the ban of corporal punishment in schools, especially in public schools running under the supervision of government. Some of the public-school teachers favored this ban and they felt that it is a good sign because it reduces fear among student and enhances their critical and analytical thinking. It also reduces drop out ratio because many students leave school due to the fear of punishment. On the other hand, some of the participants were against this ban. According to them, it is needed because without the fears of punishment student don't obey the rules and regulation, it also has negative effects on their study.

The government of Pakistan has taken social and administrative measures to ban corporal punishment in all educational institutions and raise the slogan "Maar Nahi Piyar" to secure the right of children against corporal punishment. In this regard, various efforts were made. A bill was presented the National assembly of Pakistan to make the provisions for the prohibition of the Corporal punishment against children entitled "Prohibition of Corporal Punishment Bill, 2014". On the provincial level, provincial governments of provinces of Pakistan also took the initiatives to stop the corporal punishments in the schools. For example, in 2016, government of Sindh passed the bill of corporal punishment which later promulgated as an Act No. VII of 2017 "Sindh Prohibition of Corporal Punishment Act, 2016". Similarly, the government of Khyber Pakhtunkhwa also initiated the decision to ban on the corporal punishment and enforced the act "The Khyber Pakhtunkhwa Child Protection and Welfare Act, 2010" (Khyber Pakhtunkhwa Act No. XIII of 2010).

Corporal punishment is a matter of concern for the students, teachers, school administration and the policy makers. As it is a common practice of schools to punish the students when their discipline and academic achievement is in danger. But to secure the physical, social and psychological rights of children, $\mathrm{CP}$ has been banned by the Government of Pakistan like other countries. But the flip side of this situation may present a different picture. When the said policy is seen in case of school discipline, it is prohibited to a teacher to physically punish a student and at the same time they have to develop them as disciplined and civilized member of the society. Such situation has created a challenge for the teacher, as his perception and belief may affect his commitment to practice this ban in true letter and spirit. This arises the question that how do policy practitioners perceive the ban on corporal punishment? What problems are related to policy practitioners regarding corporal punishment ban in secondary education institutes? To answer these research queries, the present work explained and explored the efficiency of Corporal Punishment Policy in district Sargodha.

\section{Objectives of the Study}

The research work was comprised of following objectives.

1. To investigate the perception of the teachers as policy practitioners regarding ban enacted by the government on corporal punishments in schools.

2. To explore the factors which hindered the policy practitioners to implement the corporal punishment.

\section{Methodology}

To explore the said issue, a qualitative phenomenological research approach was used. Therefore, a criterion sampling technique was adopted for this study because it is the suitable strategy to get rich 
information from a smaller number of participants which are selected on the predetermined criteria. Here in this paper, the predetermined criteria was the ten years of working experience in public elementary schools. There are seven tehsils in the Sargodha district, therefore, at first stage three tehsils were selected which were having greatest number of elementary schools, these were Sargodha (141 schools), Silanwali (57 elementary schools) and Kotmomin (40 elementary schools).

Afterwards, 10 teachers fulfilling the criteria of the study from ten schools from each tehsil were selected. Total 30 teachers were interviewed till the saturation of the data occurred. These phenomenological interviews were primarily based on open-ended questions. The duration for each interview was 40 to 50 minutes, and a prior permission from the school heads and consent of the interviewees were obtained.

The data was analyzed by following the overall process guided by Creswell (2013). The similar ideas and themes were generated from the data and was presented through the major themes.

\section{Results \& Discussion}

The themes were emerged from the 30 interviews collected from the public sector elementary school teachers. The interviewees were requested to express their perception about the ban on corporal punishment. The major themes and the sub theme emerged from collected data are explained in this section.

\subsection{Theme 1: Perceptions of Teachers regarding Ban Corporal Punishment}

Before the ban on corporal punishment, it was considered as a method of discipline that creates fear among child and increases a child's capability to be an independent and responsible individual. In the public elementary schools, corporal punishment was the major tool to keep the children in control. Conventional corporal punishment is not in practice now a days as the disciplinary actions in most of the schools. It has been replaced by the alternative forms of the punishments such as; community services, additional study assignments after school time, in-school suspension etc.

\subsection{Sub Theme 1: Behind the Curtain: Practice or Ban}

It was found that most of the teachers of the public elementary school applying corporal punishment instead of its ban to control the class. In their view, without corporal punishment they cannot maintain the class discipline means. Although corporal punishment is banned in schools, there are no hard and fast rules to monitor this in our schools. There are many other ways to punish the children e.g. gives them mental stress, discriminatory behavior, slapping, and abusing, etc. In Pakistani cultural context, there are many laps in the socialization of children in the household and society level. Children are trained in a say they don't bother anything without the fear of punishment at both household and school level. When were asked about the practice of corporal punishment in their school, most of them were of the view that;

Yes, sometimes, I practice corporal punishment because we cannot handle the students in the class so I prefer to use mild corporal punishment. It is done on school's directions which permit us to punished students without any harm.

Another participant explained

Yes, it is practiced in our school and I had also practiced it because it used by the teachers when all method became fail to improve the academic performance of students, so I prefer to use corporal punishment for some students.

Some other stated as,

No, there is no use of corporal punishment in our school and all of the teachers in our school are restricted to treat with students in a lenient way. 
Although many teachers explained their practice of using corporal punishment, others are following the ban.

\subsection{Sub Theme 2: Personal Views of Teachers about Corporal Punishment}

It has generally assumed that corporal punishment is essential to for students to learn discipline and helps them to achieve educational tasks during the academic session. The discipline is considered as a branch of teaching that improves self-discipline and helpful in personality development. However, corporal punishment is necessary or not necessary for discipline maintenance, in this context participants gave their personal views and explained that

Yes, I think corporal punishment is necessary to maintain the discipline because students do not obey the teachers without punishment that's why punishment is necessary to control the harsh behavior of students. When schools paddled children who misbehave, the children behave better. Therefore, I believed if teachers will leave corporal punishment it will spoil the students.

Another opined that,

According to me up to some extent, it is necessary to maintain the discipline at school because sometimes you cannot control the student behave accordingly. They don't understand your point and don't obey you so; I consider corporal punishment is necessary for some times.

Another explained that

No, I never ever think that corporal punishment is necessary for any institution to maintain the discipline not only for our institution but all other educational institutions or madrassa physical punishments do not fit properly, but, I believe we use alternative method of discipline instead of corporal punishments so, as it is in Islam against the use of physical force and our Holy Prophet PBUH also used the way of love to convince people and our religious also teach this thing. If we use physical force to maintain the discipline it creates a negative impact on children and they teach this thing or practice at home that's why I have never favored the use of corporal punishment in any institutions.

Another clarified that

Corporal punishment is not needed because it damages the personality of student and students are discouraged when teacher or give any other kind of punishment. I know that it is difficult to maintain discipline without punishment, but I use different strategies to manage it. I think that it is the right decision of the government for the welfare of students. It is good because due to corporal punishment students become rebels and it affects their study so I believe that you can teach moral values; ethics to students instead of punishment' ever since punishment is most dangerous for the student's career and also for the nation.

\section{Another teacher explained that}

It is a good step and it also encourages the slogans of "Maar Nahi Pyaar" because sometimes teachers used so much punishment to handle students because they think the punishment is the only way to control the students and it also effects on the student mind, as a result, they even deviate from their goal in spite of being better. 
Most of the teachers replied that corporal punishment is necessary to improve the condition of students. They also said that it should be applied only when all other alternative disciplinary measures are failing to improve the discipline condition.

\subsection{Sub Theme 3: Corporal Punishment Ban and Practitioner's Awareness}

When respondents were asked about the Corporal Punishment Act, 2010, they stated that,

Yes, I know about the corporal punishment Act 2010 that imposed ban on corporal punishment. The punishment was banned for students because at that time a lot of incidences happened related to child's corporal punishment. Even some children died due to the excess of corporal punishment. So, the government passed the rule and make this Act for child protection, and according to this act, teachers follow the "Maar Nahi Piyar" policy to deal with students in school.

Another opined,

Yes, I am aware of this I have read many times this slogan" Maar Nahi Piyar" (love instead of punishment) written on the walls and boards of schools. But I am not aware of enacted law by the government.

Another participant explained that

I know about in the news that corporal punishment is outlawed. But, I do not have any exact evidence of the prohibition.

Another respondent said,

The law passed by the National Assembly could not apply in every context.

I have seen in an update that corporal punishment is not allowed, but, our school administrator had not given any information on the prohibition of corporal punishment. We use corporal as usual.

Most of the participants stated that they have no clear information about the ban and very few participants are aware of this law.

\section{Theme 2: Post Corporal Punishment Legislation Challenges}

The data from the interviews revealed that there is a lot of problem and challenges faced by the teachers for the implementation of the ban on corporal punishment.

\subsection{Sub Theme 1: Post Corporal Punishment Legislation Problems of Teachers}

The ban on the corporal punishment create problems for teachers as they cannot maintain discipline or enhance the performance of students as compared to before the ban so it also affects the teacher's performance as well. Some teachers indicated that,

I also perceived various challenges in the implementation of the policy because after the ban on corporal punishment I face negative attitude of the students in form of misbehavior and get poor performance because the students have no fear of punishment or they become careless.

I think teachers feel powerless after the ban. The rule that we cannot expel students has created so much disorder in schools that we cannot perform our essential duties. Further, they consider that the new discipline pattern is not in the best interest of students. It has become increasingly difficult for teachers to discipline and motivate students to work 
hard in their studies.

Many participants explained that in our society the ban of punishment created many problems regarding discipline and education performance of students. But now the problem is fear of school administration revolves around FIR and fine in case of using corporal punishment. In this context, some teachers indicated that

They avoid corporal punishment to protect the positive image of their school because they are afraid about police involvement on the school campus as the news spread rapidly on mass media.

Another explained that

I think alternative measures are good, but the problem is that teachers are not properly applying these alternatives as compared to corporal punishment because this was simply presented to educators without training.

Another teacher indicated that

Ban on corporal punishment is not fruitful for students' personality grooming in schools. As I notice that after the ban of corporal punishment, students use to talk to us in a frank manner which was not observed previously. Even some students make fun of teachers and they cannot say anything due to this ban. Teaching is the most respectful profession and as teachers we are used to receive respect always so on such moments we feel, helpless, disgraced and angry. But we have to control over anger because no such complaint is received by the school administration. We are teachers but we feel as students of this generation lead us.as a result, students are missing the required socialization $\mathrm{f}$ their time.

\subsection{Sub-theme 2: Current Discipline Condition in Public Elementary Schools}

Corporal punishment is given to the students to maintain discipline and their performance. The purpose of corporal punishment is also to correct the behavior of children and maintain and order in the school. Many participants explained that after the ban of a corporal punishment a lot of issues regarding discipline occurred. In this context, a teacher explained that

It is very difficult for me to maintain discipline in class and I have faced serious cases of indiscipline by the students. There are a lot of cases of student's misbehavior and they beat another innocent fellow student when I go out the class. Now they have no fear of punishment thus maintaining the discipline is quite difficult in the class.

It is clear from the above statement by the teacher that it is difficult to maintain discipline in class in the absence of corporal punishment. Other teachers opined that

"I think before this ban students were paying more attention to their studies and were well-disciplined because they have a fear of punishment, but after the ban, they feel free from punishment and not attend a lesson attentively or do not perform better in the class. But now the students misbehaved with teachers because they know the teacher cannot punish them. This behavior of students is very bad for the student's future".

"I perceived that before the ban teachers were freely punishing their students, how much they want they punish, and sometimes some teachers used very worst methods for discipline, but after the ban, I use alternative strategies of discipline to maintain and one 
rule the students. Because now teachers cannot easily just a slap to students because they have a fear that they can be arrested in case of corporal punishment".

No, but sometimes if any student behaves rudely, I can handle this situation with different techniques like counseling. Children in the primary section are in search of love. If they do not find love, or if they find harsh words or harassment from someone then they show misbehaved sometimes. So, I handle this situation very calmly. I show them care, love and benevolence. Because I think the teacher should handle this situation very carefully.

Most of the participants indicated that they are facing difficulties to ensure discipline in class after the ban on corporal punishment. Some teachers were frustrated to give up the responsibility of maintaining discipline in class because they think the alternative discipline measure is not working effectively as corporal punishment. On the other hand, some public elementary school teachers mentioned that their class discipline is good because they use small curriculum activities to engage the students in class.

\subsection{Theme 3: Opinion of Teachers regarding Government Policy on CP}

The majority of the participants did not support the ban on corporal punishment as they were of the view that this ban increased indiscipline in schools. Consequently, all of the participants specified that light punishment should be needed enough to change unwanted behavior. But they also argued that punishment should never take a severe form.

\subsubsection{Sub Theme 1: Perceptions of Teacher's towards Policy Implementation}

The purpose of this theme is to explain the teachers' perceptions about the policy which imposes ban on corporal punishment. The data revealed that most of the teachers were not contented with the ban on corporal punishment. As many of them mentioned that,

No, I am not satisfied with the government policy and government should not ban it totally because if the child has no fear of punishment they cannot take an interest in the study so I believe that rules must be flexible that teacher would not beat the student harshly but they create fear of punishment in their heart through light punishments.

I think government policy regarding the ban on corporal punishment is not suitable for existing situations because now students become spoiled due to social media so sometimes teachers required punishing them but it should not exceed to beating.

The participants revealed that policy to ban corporal punishment is creating difficulties for teachers to maintain discipline because some of the teachers are not trained to use another alternative method of discipline.

Some other public elementary school teachers pointed out that present corporal punishment policy is a good initiative by the government. They further explained that

Yes, I am satisfied somehow because it is good for those government schools where teacher taking extra advantages or badly beat; thus creating a bad effect on student' health.

Teachers opined that government policy on corporal punishment ban is one-sided because it only favors students. They think that before the ban on corporal punishment they can easily tackle students' learning and behavior problems. Though after this legislation, now they are facing many problems regarding discipline management in class. So they believe it has affected the whole school environment.

\subsubsection{Sub Theme 2: Participants' Opinion regarding the Modification of Policy}

When teacher as policy practitioners were asked about the modification of policy, they opined that 
Yes, according to my opinion, it should be modified because every policy has some positive or negative impact after its implementation so its non-beneficial aspects should be modified. Moreover teachers' opinion should also be included in policy formulation.

Another said that

Government should modify such policy and should not generalize it. The action should be taken for only those teachers who physically injure the student, but not for those who use such light punishment that enhances the performance of the student".

Some other participants mentioned that

Yes, I think it should be changed and punishment should allow during the school because nowadays children become spoiled so light punishment should be allowed for their rude behavior

Some participant favored such corporal punishment policy as they explained

No, I think, so it is good policy or never change it because it helps me to establish a positive learning relationship with students that based on mutual respect and respect for the right of the other. formulation.

Teachers are in the favor of modification of policy and they also wanted to be a part of policy

5.3.3 Sub-theme 3: Participants Suggestion regarding the Policy Implementation and Modification When teachers were asked to give suggestion regarding the policy implementation and modification most of them presented the following suggestion

I suggest that mild corporal punishment should be allowed in schools and must be applied by the teachers because students do not pay attention in their studies without punishment.

I think the mild corporal punishment is an effective and successful way of maintaining discipline and strengthening students' academic achievement because the students complete their homework and perform well in daily/weekly inspections as a result of light corporal punishment. Therefore, I believe that mild corporal punishment should be applied.

I suggested that policy implementation should be in such a manner that students and teacher do not feel humiliation in adopting such polices or teacher must be guided how to face learner or behavior problem of students.

I would like to suggest that the government should build a practical mechanism to follow the practice of educational policies in school. Further, I believe a teacher should be taught in a humble and lenient way and avoid harsh punishment because which thing is possible, that can be done by the lenient way so why we use harsh and hard way. There should be legal action against those and schools where harsh punishments constantly used.

Another participant suggested that

I think after the ban on corporal punishment government should invest more for the training of the teachers to raise their knowledge on making their teaching effective and attractive through the use of other alternative discipline methods to cope up with this serious problem. 
The most of the teachers recommended that corporal punishment should be reduced, but not be banned because teachers generally felt disempowered in their ability to handle the class. In explaining the reason of it, they opined that the mild punishment may provoke fear and respect for teachers among them which will help in improving the learners' academic achievement. Furthermore, they added that remidial classes, additional work assignments, daily or weekly assessments would be in practice as an effective strategies to tackle the behavioral issues of the students and those who show poor performance.

Moreover, the government should implement policy in such a way that is acceptable for both students and teachers. They believed that the use of mild corporal punishment to manage class discipline does not go against any law and it played an important role in increasing the performance of students at the primary school level.

\section{Conclusion}

Corporal punishment of students in different countries has been perceived as a serious concern of the governments resulted in the implementation of corporal punishment policy which strictly bans such punishments. The same scenario was observed in Pakistan when it banned corporal punishment under Corporal Punishment Act, 2010. Though the policy was implemented to save children from cruel punishments at different places, we discussed it at primary school level. The purpose of this article was to study the perception and the problems faced by the teachers as policy practitioners with regard to ban on corporal punishment. They confront certain challenges and face problems in its implementation.

The conclusion of this paper reveals that the said policy was implemented by the state as rights-based principle. As Pakistan was a signatory of international treaties so it had to implement such policies under the international umbrella. It followed the pattern of other countries that banned CP without realizing the consequences. Moreover, the pressure groups like child welfare non-profit organization lays a great stress on state to pass such laws. Some groups consider media as a pressure group; but it has just a catalytic action in the society. To be more concise, the state vision to promote child welfare is hardly seen through its policies as at the end the welfare of the target group must be assured not doubted.

During the policy formulation, the policy stakeholder's opinion is always welcomed to secure the chances of its success; but it was not the case in corporal punishment policy. Teachers as one of the stake-holder are of corporal punishment policy; are seen mostly reactive with corporal punishment policy. It is an imposed model which does not include teachers' opinion as they are the policy practitioners and have to face the consequences of the policy first. If by chance there is teachers' inclusion for some policy discussions, teacher' union representatives are called who are selected on votes not due to teaching performance. Despite the fact physical social and mental torture should not be allowed, teachers are vulnerable when they have to deal with a group of students without the authorization of discipline maintenance. Their authorization in the public elementary schools is restricted to a level that they are not allowed to socialize the students against their will. This creates desperateness in this auspicious profession.

In the light of these conclusions, it may be suggested that government might address the problem of corporal punishment in school by having a broader recognition of the problem. The cases of different children might be dealt differently by a collaborative group of teachers, parents and administration. The policy should deal the school students in different manner to secure their future. The policy should be amended to facilitate the teachers and maintain the discipline of the schools.

\section{References}

Creswell, J. W. (2013). Qualitative inquiry and research design: choosing among five approaches (2nd Ed.). Thousand Oaks, CA: Sage.

Fournier., J. L. (2004). Mouchons nos morveux, Pour ou contre la fessée. Livre de Poche Paris: SARI.

Gershoff, E. T., \& Grogan-Kaylor, A. (2016). Spanking and child outcomes: Old controversies and new meta-analyses. Journal of Family Psychology, 30, 453-469.

Gershoff, E. T., Goodman, G. S., Miller-Perrin, C. L., Holden, G. W., Jackson, Y., \& Kazdin, A. E. (2018). The strength of the causal evidence against physical punishment of children and its 
implications for parents, psychologists, and policymakers. American Psychologist, 73(5), 626638

Gershoff, E. T. \& Bitensky, S. H. (2007). “The case against corporal punishment of children:converging evidence from social science research and international human rights law and implications for U.S. public policy. Psychology, Public Policy and Law. 13(4): 231-272.

Gershoff, E. T., Goodman, G. S., Miller-Perrin, C., Holden, G. W., Jackson, Y., \& Kazdin, A. E. (2019). There is still no evidence that physical punishment is effective or beneficial: Reply to Larzelere, Gunnoe, Ferguson, and Roberts (2019) and Rohner and Melendez-Rhodes (2019). American Psychologist, 74(4), 503-505. https://doi.org/10.1037/amp0000474

Hadi, H. (2014). Corporal punishment: heralding discipline or psychological ill health? JPMS Medical Blogs. Retrieved from https://ecommons.aku.edu/pakistan_fhs_son/297

Mararike, C. (2005). Spare the rod, save the child. Johannesburg IRIN.

Raj, L. (2011). Understanding corporal punishment in India. Career Educator: An Interdisciplinary Education Journal, 1 (1), 3-18.

Shmueli, B. (2010). Corporal Punishment in the Educational System versus Corporate Punishment by Parents: A Comparative View. Law and Contemporary Problems, 73, 281-320.

UNICEF (2012). Child discipline: The challenges and progress. Retrieved from http://www.childinfo.org/discipline.html.

Sindh Provincial Assembly (2017). Retrieved from http://www.pas.gov.pk/uploads/acts/Sindh\%20Act\%20No.VII\%20of\%202017.pdf on May 05, 2019.

KPK Child Protection Act (2010). Retrieved from http://kp.gov.pk/uploads/2016/02/2._Child_Protection_and_Welfare_Act,_2010_pdf

On May 05, 2019.

$\begin{array}{llll}\text { Pakistan } & \text { National } & \text { (2010). } & \text { Retrieved }\end{array}$ http://www.na.gov.pk/uploads/documents/1397730810_455.pdf on May 05, 